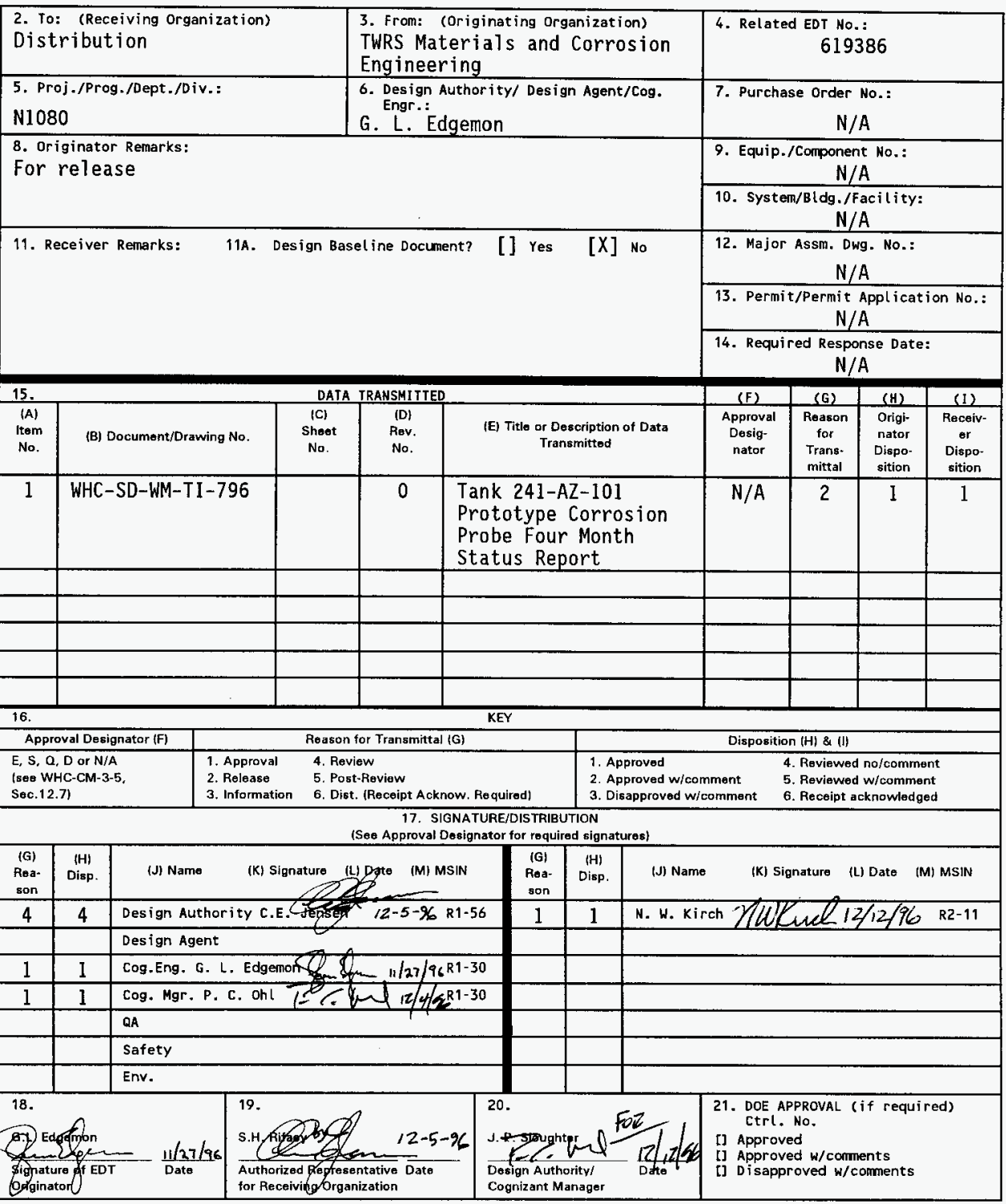




\section{Tank 241-AZ-101 Prototype Corrosion Probe Four Month Status Report}

G. L. Edgemon, J. L. Nelson, P. C. Ohl

Lockheed Martin Hanford Corporation, Richland, WA 99352

U.S. Department of Energy Contract DE-AC06-87RL10930

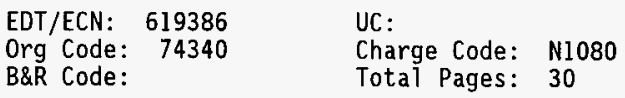

Key Words: waste tank corrosion, electrochemical noise, pitting, stress corrosion cracking, localized corrosion, mild steel, nitrates, corrosion surveillance, corrosion monitoring

Abstract: This report summarizes the first four months of field operation of a prototype electrochemical noise based corrosion monitoring system installed in tank 241-AZ-101 in August, 1996.

TRADEMARK DISCLAIMER. Reference herein to any specific commercial product, process, or service by trade name, trademark, manufacturer, or otherwise, does not necessarily constitute or imply its endorsement, recomendation, or favoring by the United States Goverrment or any agency thereof or its contractors or subcontractors.

Printed in the United states of America. To obtain copies of this document, contact: WHC/BCS Document Control Services, P.O. Box 1970, Mailstop H6-08, Richland WA 99352, Phone (509) 372-2420; Fax (509) 376-4989.
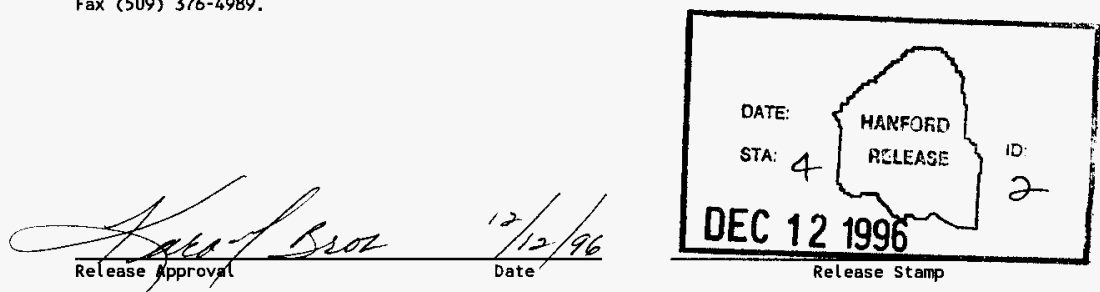

Approved for Public Release 
Rev. 0

\title{
Tank 241-AZ-101 Prototype Corrosion Probe Four Month Status Report
}

\author{
G. L. Edgemon \\ J. L. Nelson \\ P. C. Ohl \\ Lockheed Martin Hanford Corporation \\ G. E. C. Bell \\ M. J. Schiff \& Associates, Inc. \\ Date Published \\ October 1996
}

Prepared for the U.S. Department of Energy

Assistant Secretary for Environmental Management

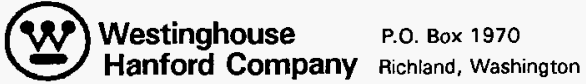

Management and Operations Contractor for the

U.S. Department of Energy under Contract DE-ACO6-87RL10930

Approved for public release; distribution is unlimited 

FOUR MONTH STATUS REPORT

G. L. Edgemon, J. L. Nelson, P. C. Ohl Lockheed Martin Hanford Corporation

P. O. Box 1970, MSIN: R1-30 Richland, WA 99352

G.E.C. Bell

M. J. Schiff \& Associates, Inc.

1291 North Indian Hill Boulevard

Claremont, CA 91711-3897 


\begin{abstract}
High-level nuclear wastes at the Hanford Site are stored underground in carbon steel double-shell and singleshell tanks. The installation of a prototype corrosion monitoring system into double-shell tank 241-AZ-101 was completed in August, 1996. The system monitors fluctuations in corrosion current and potential (electrochemical noise) occurring on three electrode arrays immersed in the waste liquid and in the vapor space above the waste. The system also supports the use of Tafel and linear polarization resistance testing. By monitoring and analyzing the data from these techniques, changes in the corrosive characteristics of the waste have been rapidly detected and correlated with operational changes in the tank.
\end{abstract}

Keywords: electrochemical noise, pitting, stress corrosion cracking, localized corrosion, nuclear waste tank corrosion, mild steel, nitrates, corrosion surveillance, and corrosion-monitoring.

\title{
INTRODUCTION AND BACKGROUND
}

The Hanford Site has 177 underground waste tanks that store approximately 253 million liters of radioactive waste from 50 years of plutonium production [1]. Twenty-eight (28) tanks have a double-shell and are constructed of welded ASTM A537-Class 1 (UNS K02400), ASTM A515-Grade 60 (UNS K02401), or ASTM A516-Grade 60 (UNS K02100) material. The inner tanks of the double-shell tanks were stress relieved following fabrication. One hundred and forty-nine (149) tanks have a single shell, also constructed of welded mild steel, but not stress relicved following fabrication. Tank waste is in liquid, solid, and sludge forms. Tanks also contain a vapor space above the solid and liquid waste regions. The composition of the waste varies from tank to tank but generally has a high $\mathrm{pH}(>12)$ and contains sodium nitrate, sodium hydroxide, sodium nitrite, and other minor radioactive constituents resulting from plutonium separation processes [1-4]. Leaks began to appear in the single-shell tanks shortly after the introduction of nitratebased wastes in the 1950s. Leaks are now confirmed or suspected to be present in a significant number of single-shell tanks [1]. The probable modes of corrosion failures are reported as nitrate stress corrosion cracking (SCC) and pitting [2].

Previous efforts to monitor internal corrosion of waste tank systems have included linear polarization resistance (LPR) and electrical resistance techniques [5-6]. These techniques are most effective for monitoring uniform corrosion, but are not well-suited for detection of localized corrosion (pitting and SCC). The characterization of electrochemical noise (EN) for monitoring waste tank corrosion was investigated by the Savannah River Site, but the tests were not conclusive [7].

For many years, EN has been observed during corrosion and other electrochemical reactions, and the phenomenon is well established [8-19]. Typically, EN consists of low frequency $(<1 \mathrm{~Hz})$ and small amplitude signals that are spontaneously generated by electrochemical reactions occurring at corroding or other surfaces [20]. Laboratory studies and recent reports on field applications have reported that EN analysis is well suited for monitoring and identifying the onset of localized corrosion, and for measuring 
uniform corrosion rates [14-27]. A two year laboratory study was undertaken to provide a technical basis for using EN in nuclear waste systems [28].

A typical EN based corrosion-monitoring system measures instantaneous fluctuations in corrosion current and potential between three nominally identical electrodes (a working, a counter, and a pseudo-reference electrode) of the material of interest immersed in the environment of interest. Time-dependent fluctuations in corrosion current between the working and counter electrodes are described by electrochemical current noise. Time-dependent fluctuations of the difference in the corrosion potential between the working/counter electrode assembly and the pseudo-reference electrode are described by electrochemical potential noise. Since the working and counter electrodes are electrically joined by a zero resistance ammeter (ZRA), potential differences are measured between the working/counter electrode assembly and the pseudoreference electrode. It has been shown that each type of corrosion phenomenon presents a unique relationship between corrosion current and potential transients in the temporal data [8-28]. Other methods of analysis involve transforming temporal data to the frequency domain for analysis [29].

In April, 1995, tank 241-AZ-101, located in the AZ tank farm of the 200 East area of the Hanford Site, was selected for prototype deployment of an EN based corrosion monitoring system. The tank was placed into service in 1976. The primary liner of the tank is constructed of ASTM A515-Grade 60 carbon steel to store neutralized current acid waste, a high-level waste produced from the reprocessing of irradiated nuclear fuels in the Plutonium Uranium Extraction plant (PUREX). The tank first received water in late in 1976. During the next seven years, it received a mixture of evaporator feed, double-shell slurry feed, complexed, noncomplexed, and dilute noncomplexed waste from PUREX and other miscellaneous streams [30]. From 1984 through 1986, the tank received aging waste from the PUREX plant exclusively. The remainder of the fill history of tank 242-AZ-101 consisted of a series of small additions of water and dilute noncomplexed wastes from other double-shell tanks [30]. As of August 1996, 241-AZ-101 contained a total of 3.2 million liters of liquid supernate waste and sludge. This volume fills the tank to an approximate depth of $782 \mathrm{~cm}$. This fill level comprises approximately $33 \mathrm{~cm}$ of solid sludge at the bottom of the tank, with the remainder as liquid supernate. Waste chemistry and operating conditions are shown in Tables 1 and 2.

On August 1, 1996, the prototype EN based corrosion monitoring probe was installed in tank 241-AZ-101. This paper summarizes the design, development, and data collected from the prototype probe during its first four months of operation.

\section{SYSTEM DESIGN AND CONFIGURATION}

The prototype corrosion monitoring system is designed to detect the onset of localized corrosion phenomena if tank conditions should change to allow these phenomena to occur. The system also facilitates the use of the Tafel and LPR techniques to collect uniform corrosion rate information. 
The following design goals were established for the prototype probe system:

- Provide at least two years of service
- Fit through $10 \mathrm{~cm}$ diameter riser
- Facilitate remote data acquisition and system control
Facilitate decontamination by minimizing liquid retention

The probe system was designed to operate under the following conditions:

- Temperature ranges up to $100^{\circ} \mathrm{C}$

- $\quad$ Liquid phase $\mathrm{pH}$ ranges from 7 to 14

- Radiation levels up to $1000 \mathrm{R} / \mathrm{hr}$

- Liquid phase flow rates up to $1.0 \mathrm{~m} / \mathrm{s}$

A schematic diagram of the corrosion monitoring system is shown in Figure 1. The prototype corrosion probe is constructed from $3.8 \mathrm{~cm}$ diameter AISI 304L stainless steel (UNS 30403) pipe for extended service in the waste tank environment. It fits through a nominal $10.2 \mathrm{~cm}$ diameter tank riser and is approximately 10 meters long.

The probe has electrode arrays at the $3.9 \mathrm{~m}, 8.8 \mathrm{~m}$, and $9.9 \mathrm{~m}$ depths. The upper two electrode arrays are positioned to monitor vapor phase corrosion, while the lower most array is immersed approximately $55 \mathrm{~cm}$ into the liquid waste. The probe tree assembly is shown in Figure 2. Each electrode array consists of three nominally identical C-ring (ASTM G-38) electrodes constructed of archived ASTM A537-Class 1 tank steel to best represent actual tank wall material (Figure 3). The working (center) electrode in the liquid phase array was pre-cracked by cyclic fatigue and strained beyond the proportional limit just prior to immersion in the waste. The other two liquid phase electrodes were not strained. The working electrodes of the vapor space arrays were not pre-cracked, but were strained beyond the proportional limit prior to installation.

A 10 conductor shielded data cable extends through the length of the interior of the sealed pipe. At each electrode array, three conductors are removed from the shielding and attached to the three electrodes, one per electrode. A commercially available glass to metal seal is used to penetrate the probe tree pipe wall while maintaining electrical isolation between the electrodes and the pipe wall. Electrodes are isolated from the glass to metal seal through the use of an ethylene propylene (EPDM) gasket suitable for use in radiation environments. The shielded cable terminates at the top to the probe tree assembly in a weather tight box. Approximately 24 meters of above ground cable runs from the top of the probe to the corrosion monitoring instrumentation. The above ground cabling is shielded from electrical interference with driven Faraday shields emanating from the corrosion monitoring instrumentation. 
The corrosion monitoring instrumentation utilizes a Gamry Instruments CMS100 electrochemical measurement system with an eight channel multiplexer and associated software. ${ }^{1}$ Galvanic corrosion operating software for this system was customized and optimized for EN data collection. Data are collected sequentially on the electrode arrays using three channels of the multiplexer. Potential and current measurements are recorded once per second on the active array. Data are typically collected for 600 seconds per channel. Post-collection data analysis is performed using internally developed statistical analysis software and Microsoft Excel. ${ }^{2}$ Data acquisition began following electronics package installation on August $8,1996$.

\section{PRELIMINARY RESULTS AND DISCUSSION - LIQUID ARRAY DATA}

\section{Summary Statistical Data}

Summary statistical data for the first four months following probe installation are shown in Figures 4 through 11. Although it is not strictly possible to distinguish between forms of corrosion using statistical data alone, statistical analysis of the raw data files is useful in identifying time periods of change in corrosion behavior. By limiting preliminary raw data analysis to files associated with large changes in the summary statistical data, time spent on data analysis was greatly reduced. Gaps in the summary statistical data indicate loss of data due to equipment disturbance, maintenance, and power failures. The largest loss of data came over a 146 hour period between 10/23/96 and 10/29/96.

During the four month monitoring period, the largest changes in tank corrosion behavior were the result of raw or inhibited water additions to the tank. Water is added to the tank during thermocouple removal and replacement operations and to replace volume losses due to evaporation. Tank volume over the course of the four month monitoring period is shown in Figure 4. Table 3 summarizes the water additions evident in Figure 4.

Mean current is shown in Figure 5. Mean current ranged from approximately $-7 \times 10^{-6}$ to $3 \times 10^{-6} \mathrm{~A}$ and generally decreased over time. The current convention on the zero resistance ammeter in the monitoring system was set to record a positive current when the working electrode was anodic with respect to the counter electrode. The effect of raw water additions made on $9 / 10 / 96,9 / 20 / 96,10 / 3 / 96$, and particularly $10 / 24 / 96$ can be clearly seen. Mean current decrease during the water additions is thought to be due to waste oxygenation and mixing causing a temporary increase in passive film thickness. Water injection likely forces waste with high hydroxide concentrations from deep within the tank upward to mix with waste with lower hydroxide concentrations near the surface.

1 Gamry and CMS100 are trademarks of Gamry Instruments, Inc., Willow Grove, Pennsylvania.

2 Microsoft and Excel are registered trademarks of Microsoft Corporation, Redmond, Washington. 
Mean potential difference between the working/counter electrode assembly and the pseudo-reference electrode is shown in Figure 6. The initial potential difference was approximately $10 \times 10^{-3} \mathrm{~V}$, with the working/counter electrode assembly anodic with respect to the pseudo-reference electrode. In general, mean potential difference decreased steadily over time. The effect of the raw water additions and a Tafel scan conducted on $9 / 12 / 96$ are also evident.

The standard deviation of current is shown in Figure 7. The standard deviation of current prior to the large water addition on 10/24/96 was approximately $2 \times 10^{-7} \mathrm{~A}$. Small temporary decreases in standard deviation of current can be seen following water additions on 9/10/96 and 10/3/96. In both cases, the standard deviation of current returned to pre-water addition levels within a few days. An extremely large increase up to approximately $4 \times 10^{-6} \mathrm{~A}$ was recorded on 10/29/96 following the water addition on 10/24/96. The standard deviation of current was still decreasing as of 11/20/96.

The standard deviation of potential is shown in Figure 8. The standard deviation of potential prior to the large water addition on 10/24/96 fluctuated near the equipment's limit of detection at $1 \times 10^{-4} \mathrm{~V}$. Small temporary increases in the standard deviation of potential can be seen following water additions on 9/10/96 and 10/3/96. In both cases, standard deviation of potential returned to pre-water addition levels within a few days. An extremely large increase up to approximately $5 \times 10^{-3} \mathrm{~V}$ was recorded on 10/29/96 following the water addition on 10/24/96. The standard deviation of potential was still decreasing as of 11/20/96.

The pitting index $(\mathrm{PI})$ for the four month monitoring period is shown in Figure 9. The PI parameter has a maximum value of 1.0 and is defined as,

$$
\mathrm{PI}=\sigma \mathrm{I} / \mathrm{I}_{\text {rms }}
$$

where $\sigma \mathrm{I}$ is the standard deviation of current and $\mathrm{I}_{\mathrm{ms}}$ is the root mean square of current flowing between the counter and working electrodes. Values of PI close to 1.0 are reported to indicate the onset of localized corrosion, whereas lower values indicate uniform corrosion [7,14,19,31-33]. An increase in PI is evident in Figure 9 following water additions on 9/10/96, 9/20/96, 10/3/96, and 10/24/96. A general increase in PI is also evident over the four month monitoring period.

The resistance noise $\left(R_{n}\right)$ for a system is defined as,

$$
\mathrm{R}_{\mathrm{n}}=\sigma_{\mathrm{EPN}} / \sigma_{\mathrm{ECN}}
$$

where $\sigma_{\mathrm{EPN}}$ is the standard deviation of potential and $\sigma_{\mathrm{ECN}}$ is the standard deviation of current. Trends in $R_{n}$ over the first four months are shown in Figure 10. Average $R_{n}$ values prior to the water addition on 10/3/96 were approximately $17,000 \mathrm{ohm}-\mathrm{cm}^{2}$. The effect of the raw water additions are also evident.

The value of $R_{n}$ for a system has been reported to be equivalent to the system's polarization resistance $\left(R_{p}\right)$ $[20,32,34]$. For comparison, Figure 10 shows the $R_{n}$ data along with an average value of $R_{p}$ calculated from 
eight standard LPR tests conducted between $8 / 8 / 96$ and $9 / 25 / 96$. Instead of being equal, values of $R_{p}$ measured by $L P R$ tests were consistently $\sim 3.6$ times greater $\left(60,000 \mathrm{ohm}-\mathrm{cm}^{2}\right)$ than the $R_{n}$ values calculated from the EN data. Tafel constants (determined by Tafel extrapolation) were $\beta_{c}=46$ and $\beta_{a}=214$ $\mathrm{mV} /$ decade. Measured $R_{\mathrm{p}}$ and Tafel constants used in conjunction with the Stern-Geary equation and Faraday's laws show a general corrosion rate of less than 0.2 mils per year. Equivalent corrosion rates can be determined from EN data by multiplying $R_{n}$ by 3.6 and substituting for $R_{p}$ in the Stern Geary equation. Corrosion rates predicted by $R_{n}$ for the four month monitoring period are shown in Figure 11. These data were consistent with previous laboratory results in simulated waste solutions [35].

\section{Liquid Phase Raw Data}

As shown in Table 3, eight separate water additions were made to tank 241-AZ-101 over the first four months of operation. Of these, the additions made on $9 / 10,9 / 20,10 / 3$, and 10/24 strongly affected the summary statistical data shown in Figures 5 - 11. Raw data files from the time periods surrounding these water additions were closely investigated.

Figure 12 shows a typical raw data file collected just prior to the 2,035 gallon $(7,702 \mathrm{~L})$ water addition made on 9/10/96. Data files such as Figure 12 were typical of the first two months of operation. Similarly, Figure 13 shows a raw data file collected three days after the $9 / 10 / 96$ water addition. The current and potential signatures in these files have been shown to be characteristic of uniform corrosion [14-28]. The water addition made on 9/10/96 did not induce any form of localized corrosion on the electrodes.

Figures 14 and 15 show, respectively, raw data files collected just before and shortly after the 2,420 gallon $(9,160 \mathrm{~L})$ water addition made on $9 / 20 / 96$. As with the $9 / 10 / 96$ addition, the $9 / 20 / 96$ addition had little or no effect on the corrosion characteristics of the waste. Data files following this addition continued to be characteristic of uniform corrosion.

On 10/3/96, 7,178 gallons $(27,169 \mathrm{~L})$ of water was added to the tank. Prior to addition, this transfer was inhibited with sodium hydroxide to a concentration of $0.26 \mathrm{M}$. Figure 16 shows a raw data file collected just prior to this addition. Figure 17 shows a data file collected two days after the water addition. Data similar to Figure 17 were collected for approximately two weeks following the 10/3/96 water addition. The current and potential signatures shown in Figure 17, and those collected through $\sim 10 / 13 / 96$, have been shown to be characteristic of pit initiation and pit growth [14-28]. The current convention on the ZRA for this equipment is such that current spikes in the positive direction indicate pit initiation in the working electrode, while current spikes in the negative direction indicate pit initiation in the counter electrode. Instantaneous spikes in current are indicative of pit initiation. Current transients that persist for longer periods of time are indicative of pit growth. The equipment's sensitivity to potential is limited to $1 \times 10^{-4}$ $\mathrm{V}$. Therefore, the influence on potential of small pit initiation events such as these could not be recorded. Similar results, verified by post-test metallography, were recorded in pit-inducing waste simulants during the laboratory probe development program prior to probe installation $[28,35]$. 
Figure 18 shows a typical raw data file collected after 10/13/96. As is evident by the current and potential signature in Figure 18, the primary mode of corrosion had returned to uniform corrosion. Data files indicative of uniform corrosion were collected up to the time of the 24,612 gallon (93,156 L) water addition on 10/24/96. Figure 19 shows a typical data file collected after the 10/24/96 water addition. Pit initiation and growth returned as the dominant modes of corrosion following the 10/24/96 addition. The frequency and magnitude of current and potential transients indicative of pit initiation and growth have been steadily decreasing since the 10/24/96 addition, but subsequent water additions on 11/11/96 and 11/17/96 have hindered the return to conditions of uniform corrosion. Figure 20 shows a typical data file collected approximately 23 days after the 10/24/96 addition. The dominant corrosion mechanism in Figure 20 is uniform corrosion, but a few pit initiation transients still exist.

Vapor Space Raw Data

Data from the vapor space arrays were inconclusive with respect to both EN and LPR due to the low relative humidity. There appears to be insufficient electrolyte to support corrosion monitoring using the installed equipment. Current and potential fluctuated randomly near the limit of detection for the equipment. A slow increase in mean current is occurring as the electrodes oxidize, and future signal levels may allow further data analysis. Measured $R_{p}$ values were greater than $65,000,000 \mathrm{ohm}-\mathrm{cm}^{2}$. Redesign of the vapor space electrodes or further laboratory work with simulated vapor space conditions may permit the extraction of useful corrosion information from the existing tank vapor space data.

\section{SUMMARY AND CONCLUSIONS}

A prototype corrosion monitoring instrument tree was installed into a double-shell waste tank at the Hanford Site. The instrument tree monitors transients in corrosion current and corrosion potential occurring on three electrode arrays immersed in the waste liquid and in the vapor space above the waste. By monitoring these transients, changes in the corrosive characteristics of the waste have been rapidly detected and correlated with operational changes in the tank.

Values of $R_{p}$ measured by LPR were approximately 3.6 times greater $\left(60,000 \mathrm{ohm}-\mathrm{cm}^{2}\right)$ than the $R_{n}$ values calculated from the EN data. Tafel constants (determined by Tafel extrapolation) were $\beta_{c}=46$ and $\beta_{a}=214$ $\mathrm{mV} /$ decade. Measured $\mathrm{R}_{\mathrm{p}}$ and Tafel constants used in conjunction with the Stern-Geary equation and Faraday's laws show a general corrosion rate of less than 0.2 mils per year. For tank 241-AZ-101, equivalent corrosion rates can also be determined from $E N$ data by multiplying $R_{n}$ by 3.6 and substituting for $R_{p}$ in the Stern-Geary equation. Uniform corrosion rates calculated from EN data were also less than $0.2 \mathrm{mpy}$. The LPR technique offers a relatively accurate estimation of free corrosion rate when corrosion is assumed to be uniform. However, typical LPR equipment is not well suited for determining the active corrosion mechanism. Since EN offers information on corrosion mechanism, uniform corrosion rate estimation from EN data can be limited to data in which uniform corrosion is the only active mechanism. 
EN data collected during the first two months of operation indicated that uniform corrosion was the dominant active corrosion mechanism. No characteristic current and potential transients indicative of localized corrosion were observed. The effects of small raw water additions during thermocouple tree removal operations were recorded in the summary statistical data on $9 / 10 / 96$ and $9 / 20 / 96$, but these additions did not induce any form of localized corrosion.

Larger raw water additions made on 10/3/96 and 10/24/96 induced pit initiation and growth in the electrodes. Pitting transients were recorded for approximately two weeks following the 10/3/96 addition. Pitting induced by the 10/24/96 water addition persists, but the frequency and magnitude of pitting transients are steadily decreasing indicating a return to conditions of uniform corrosion. Data indicative of pit initiation and growth following large water additions to tank 241-AZ-101 at the Hanford site are consistent with previously published predictions of pitting behavior in waste tanks at other nuclear waste storage facilities [36].

Data collected from the Hanford Site prototype corrosion probe indicates that an EN/LPR based corrosion monitoring system can be successfully applied to nuclear waste tank environments.

\section{RECOMMENDATIONS FOR FUTURE WORK}

Although the prototype probe has performed well over the first four months of operation, there are several areas that could be optimized in future designs. Primary concerns include the design of the remotely located corrosion monitoring instrumentation, the potential sensitivity of the existing instrumentation, the dependability of the remote access system, the characterization of vapor space data, the design of the electrode/probe mast sealing surface, and the range of available tank monitoring depths.

The current prototype system design demands that a fully functional computer and potentiostat be located in the field to log data and run the corrosion monitoring software/hardware. This system is relatively expensive and is capable of performing a great number of $\mathrm{DC}$ electrochemical techniques. However, many of these techniques will likely never be used in the field. If a simpler system, primarily capable of collecting EN and LPR data could be developed, the expense of the corrosion monitoring system could be substantially reduced. Common, commercially available data loggers presently do not offer the sensitivity and response time required for EN. However, if improvements could be made in sensitivity and response time, such a system may offer an alternative to the current electronics package.

The potential sensitivity of the existing instrumentation is also a concern. The potential sensitivity of the prototype system is limited to $1 \times 10^{-4} \mathrm{~V}$. Although this level of potential sensitivity is acceptable for most standard DC electrochemical measurements, the minute fluctuations in potential associated with pit initiation and growth events in a highly passive system demand a higher degree of potential sensitivity. As is evident in Figures 12-20, much of the EN data collected from the prototype probe contains potential data that simply fluctuates randomly around the equipment's limit of detection. While large changes in potential response 
due to water additions are recordable, an increase in potential sensitivity to $\pm 1 \times 10^{-6} \mathrm{~V}$ would likely allow measurement of the potential response to pit initiation in the waste tank environment.

Another area for improvement concerns the remote operating system. As is evident in Figures 5-11, data loss due to power failure and equipment disturbances has been a recurrent problem with the prototype probe. Following a power failure or other electrical disturbance, the data acquisition system and computer are configured to return to a stable condition that allows access from a remote computer via phone line, modem, and Stac Reachout remote access software. ${ }^{3}$ In several cases over the first four months, problems with the remote access software have made trips into the field necessary to re-boot the system and re-start data acquisition. This served more as an annoyance than as a major operating problem. However, a change to more dependable commercially available remote access software or the development of a system capable of delivering data directly to the Tank Monitoring and Control System (TMACS) would allow a simpler, more automated recovery process following power surges and short-term power outages.

With the exception of some minor data loss do to remote access software problems, the prototype system has been continuously collecting vapor space corrosion data from two separate electrode arrays over the first four months of operation. However, the characterization of these data remains difficult. Since no formal studies of EN electrode exposure to nuclear waste tank vapor space environments have been performed, any analysis of the existing vapor space data from the prototype probe must be based on data from other applications of EN to industrial vapor space corrosion monitoring. A controlled series of laboratory exposures of monitored electrodes to simulated vapor space environments is needed to provide the information necessary to properly analyze vapor space data and optimize electrode design.

Radiation induced swelling and potential failure of the EPDM gaskets which electrically isolate the carbon steel electrodes from the stainless steel probe mast is another concern in the existing design of the prototype probe. Gasket failure would cause an immediate loss of data due to the formation of a galvanic couple between the carbon steel electrode and the stainless steel electrode stud which attaches the electrode to the probe body. Additionally, gasket failure would allow highly caustic tank waste to come into contact with the glass-to-metal seals which lie directly under the gasket seating surface, causing eventual failure and waste intrusion into the probe body. It is expected that the electrode gaskets on the prototype probe will last for two or more years in the extremely hostile environment of tank 241-AZ-101. The radiation levels in other tanks on the site are not as high and will not create as hostile of an environment. However, probe/electrode design could be improved to increase the life expectancy in future applications.

Finally, future probes will need a greater number of electrode arrays to allow monitoring at several depths within the supernate and the sludge layer at the bottom of the tank. The design and construction of longer probe masts is one option to provide a greater range of monitoring depth, but limited riser space on each tank makes it necessary to consider the addition of probe elements to existing or replacement equipment such as thermocouple trees and mixing pumps. New probe mast designs must be capable of withstanding forces 
WHC-SD-WM-TI-796

Rev. 0

generated during waste/water additions, mixer pump operation, and operation of air lift circulators where applicable. Similarly, future probe masts must be able to withstand the eventual sludge washing and waste removal operations leading to tank closure.

\section{ACKNOWLEDGMENTS}

This work represents the cooperative efforts of many people and organizations from diverse backgrounds and ranges of interest. The laboratory development tests for the prototype probe system were conducted over the course of two years by personnel from the Materials and Corrosion Engineering group within Lockheed Martin Hanford Corporation, the Materials Development group of the Structural Materials Research Section at Pacific Northwest National Laboratory and the Corrosion Science and Technology Group at Oak Ridge National Laboratory. The technical support of Dr. Mike Danielson of Pacific Northwest National Laboratory, Mr. Ivar Husa and Dr. Ramamohan Anantatmula of Lockheed Martin Hanford Corporation, Dr. Kevin Lawson of The Mentor_1 Group, and Mr. Matt Rhodes of Gamry Instruments Incorporated is also gratefully acknowledged.

\section{REFERENCES}

[1] P.C. Ohl, J.D. Thomson, and F.R. Vollert, "Corrosion Considerations for Life Management of Hanford High Level Waste Tanks," CORROSION/94, paper no. 142, (Houston, TX: NACE International, 1994).

[2] D.C. Lini, "Compilation of Hanford Corrosion Studies," Atlantic Richfield Hanford Company Report, ARH-ST-111, UC-70, July, 1975.

[3] J.R. Divine, W.M. Bowen, D.B. Mackey, D.J. Bates, and, K.H. Pool, "Prediction Equations for Corrosion Rates of A537 and A516 Steels in Double Shell Slurry, Future PUREX, and Hanford Facilities Wastes," Pacific Northwest Laboratory Report, PNL-5488, June, 1985.

[4] W.C Carlos, "Recommendations for Erosion/Corrosion Allowance for Multi-Function Waste Tank Facility Tanks," CORROSION/95, paper no. 449, (Houston, TX: NACE International, 1995).

[5] J.L. Nelson, "Hanford DST Corrosion Monitoring Instrument Tree," CORROSION/95, paper no. 440, (Houston, TX: NACE International, 1995).

[6] R.K. Shukla, A.J. Perkins, P.M. Bourgeois, R.J. Jaramins, W.G. Secen, and, D.J. Stroud, "Corrosion Monitoring of High Level Waste Storage Tank 8-D2 at the West Valley Demonstration Project," CORROSION/94, paper no. 121, (Houston, TX: NACE International, 1994). 
[7] J.I. Mickalonis, R.J. Jacko, G.P. Quirk, and D.A. Eden, in: Proc. First Int. Symposium on Electrochemical Noise Measurements for Corrosion Applications, ASTM STP 1277, eds. J.R. Kearns, J.R. Scully, P.R. Roberge, D.L. Reichert, and J.L. Dawson, (American Society for Testing and Materials, Philadelphia, PA, 1996) p. 201.

[8] T. Haygard and J. R. Williams, Trans. Farad. Soc. 57, (1961): p. 2288.

[9] P. Bindra, et al., Discussions of Faraday Soc. 56, (1974): p. 189.

[10] M. Fleischmann, et al., Surface Science 100-101, (1980): p. 583.

[11] G.J. Bignold and M. Fleischmann, Electrochemical Acta 19, (1974): p. 363.

[12] E. Budevski, et al., Electrochemical Acta 28, (1983): p. 925.

[13] G. Blanc, et al., Electrochemical Acta 23, (1978): p. 337.

[14] K. Hladky and J. L. Dawson, Corrosion Science 23, (1982): p. 231.

[15] D.A. Eden, J.L. Dawson, and D.G. John, U.K. Patent Application 861158, May 1986, U.S. Patent 5139627.

[16] K. Hladky, European Patent 084404A3, U.S. Patent 455709, Canadian Patent 418938.

[17] U. Bertocci, "Electrochemical Noise Analysis and Its Application to Corrosion," CORROSION/89, paper no. 24, (Houston, TX: NACE International, 1989).

[18] J.L. Dawson, D.M. Farrell, P.J. Aylott, and K. Hladky, "Corrosion Monitoring Using Electrochemical Noise Measurements," CORROSION/89, paper no. 31, (Houston, TX: NACE International, 1989).

[19] D.A. Eden, A. N. Rothwell, and J.L. Dawson, "Electrochemical Noise for Detection of Susceptibility to Stress Corrosion Cracking," CORROSION/91, paper no. 444, (Houston, TX: NACE International, 1991).

[20] D.M. Farrell, Industrial Corrosion 9, (1991): p. 7.

[21] A.N. Rothwell, T.G. Walsh, and W.M. Cox, "On Line Corrosion Investigation and Surveillance Chemical Plant Case Studies," CORROSION/91, paper no. 170, (Houston, TX: NACE International, 1991). 
[22] J.L. Dawson, et al., On-line Monitoring of Continuous Process Plants, ed. D. Butcher, (Ellis Horwood, NY, 1983).

[23] D.M. Farrell, W.M. Cox, and D. Gearey, "Multi-System Corrosion Monitoring in a Cyclic Reheat Test Facility; Phase 1,” Electric Power Research Institute Report, CS-5776, 1988.

[24] D.M. Farrell, W.M. Cox and D. Gearey, "Multi-System Corrosion Monitoring in FGD Systems; Phase 2," Electric Power Research Institute Report, CS-5734, 1988.

[25] B.C. Syrett and W.M. Cox, in: Proc. First Int. Symposium on Electrochemical Noise Measurements for Corrosion Applications, ASTM STP 1277, eds. J.R. Kearns, J.R. Scully, P.R. Roberge, D.L. Reichert, and J.L. Dawson, (American Society for Testing and Materials, Philadelphia, PA, 1996) p. 173.

[26] C.A. Lotto and R.A. Cottis, Corrosion 45, (1989): p. 136.

[27] P.E. Doherty, M.J. Psaila-Dombrowski, S.L. Harper, and W.G. Schneider, in: Proc. First Int. Symposium on Electrochemical Noise Measurements for Corrosion Applications, ASTM STP 1277, eds. J.R. Kearns, J.R. Scully, P.R. Roberge, D.L. Reichert, and J.L. Dawson, (American Society for Testing and Materials, Philadelphia, PA, 1996) p. 288.

[28] G.L. Edgemon and G.E.C. Bell, "Technical Basis for Electrochemical Noise Based Corrosion Monitoring of Underground Nuclear Waste Storage Tanks," Westinghouse Hanford Company Report, WHC-SD-WM-TI-772, November, 1996.

[29] L. Beaunier, J. Frydman, C. Gabrielli, F. Huet, and M. Keddam, in: Proc. First Int. Symposium on Electrochemical Noise Measurements for Corrosion Applications, ASTM STP 1277, eds. J.R. Kearns, J.R. Scully, P.R. Roberge, D.L. Reichert, and J.L. Dawson, (American Society for Testing and Materials, Philadelphia, PA, 1996) p. 114.

[30] K.M. Hodgson, "Tank Characterization Report for Double Shell Tank 241-AZ-101," Westinghouse Hanford Company Report, WHC-SD-WM-ER-410, 1995.

[31] K. Hladky and J.L. Dawson, Corrosion Science 22, (1981): p. 317.

[32] A.N. Rothwell and D.A. Eden, "Electrochemical Noise Techniques for Determining Corrosion Rates and Mechanisms," CORROSION/92, paper no. 223, (Houston, TX: NACE International, 1992).

[33] A.N. Rothwell and D.A. Eden, "Electrochemical Noise Data; Analysis, Interpretation and Presentation," CORROSION/92, paper no. 292, (Houston, TX: NACE International, 1992). 
[34] J.F Chen and W.F. Bogaerts, Corrosion Science 37, (1995): p. 1839.

[35] G.L. Edgemon, P.C. Ohl, G.E.C. Bell, and D.F. Wilson, "Detection of Localized and General Corrosion of Mild Steel in Simulated Defense Nuclear Waste Solutions Using Electrochemical Noise Analysis," Westinghouse Hanford Company Report, WHC-SA-3016-FP, 1995.

[36] T.C. Hsu, B.J. Weirsma, P.E. Zapp, and J.A. Pike, "Practical Guidelines for Small Volume Additions of Uninhibited Water to Waste Storage Tanks," CORROSION/95, paper no. 433, (Houston, TX: NACE International, 1995). 
Table 1: Supernate Composition of 241-AZ-101 Waste

\begin{tabular}{|c|c|}
\hline Component & 1995 Supernate Sample \\
\hline Cations & moles per liter \\
\hline $\mathrm{Al}^{+3}$ & 0.34 \\
\hline $\mathrm{Na}^{+}$ & 4.14 \\
\hline \multicolumn{2}{|l|}{ Anions } \\
\hline $\mathrm{Cl}^{-}$ & 0.0049 \\
\hline $\mathrm{F}^{*}$ & 0.083 \\
\hline $\mathrm{OH}^{-}$ & 0.67 \\
\hline $\mathrm{NO}_{3}^{-}$ & 1.06 \\
\hline $\mathrm{NO}_{2}^{-}$ & 1.20 \\
\hline $\mathrm{PO}_{4}^{-3}$ & 0.014 \\
\hline $\mathrm{SO}_{4}^{-2}$ & 0.160 \\
\hline \multicolumn{2}{|l|}{ Carbon } \\
\hline Total inorganic carbon & 0.48 \\
\hline Total organic carbon & 0.086 \\
\hline Radionuclides & microcuries per milliliter \\
\hline${ }^{137} \mathrm{Cs}$ & 1590 \\
\hline${ }^{89 / 90} \mathrm{Sr}$ & 1.20 \\
\hline
\end{tabular}


WHC-SD-WM-TI-796

Rev. 0

Table 2: Operating Conditions in 241-AZ-101

\begin{tabular}{||l|c|c|}
\hline \multicolumn{1}{|c|}{ Parameter } & Supernate & Vapor \\
\hline \hline Temperature, ${ }^{\circ} \mathrm{C}$ & 60 avg - 72 max & $15-30$ \\
\hline Humidity, \%RH & - & $60-100$ \\
\hline Radiation dose rate, $\mathrm{R} / \mathrm{hr}$ & 900 & $250-400$ \\
\hline $\mathrm{pH}$ & 13.6 & -- \\
\hline Density, $\mathrm{g} / \mathrm{ml}$ & 1.2 & -- \\
\hline
\end{tabular}

Table 3: Water Additions to 241-AZ-101

\begin{tabular}{|c|c|c|l||}
\hline Event \# & Date & Gallons $(\mathrm{L})$ & \multicolumn{1}{|c|}{ Explanation } \\
\hline \hline 1 & $8 / 4 / 96$ & $2,310(8,743 \mathrm{~L})$ & Thermocouple tree rinse and removal \\
\hline 2 & $8 / 28 / 96$ & NA & Gauge repair and replacement (no water addition) \\
\hline 3 & $9 / 7 / 96$ & $633(2,396 \mathrm{~L})$ & Gauge repair (no water addition) \\
\hline 4 & $9 / 10 / 96$ & $2,035(7,702 \mathrm{~L})$ & Thermocouple tree rinse and removal \\
\hline 5 & $9 / 20 / 96$ & $2,420(9,160 \mathrm{~L})$ & Thermocouple tree rinse and removal \\
\hline 6 & $10 / 3 / 96$ & $7,178(27,169 \mathrm{~L})$ & Inhibited condensate transfer $(0.26 \mathrm{M} \mathrm{NaOH})$ \\
\hline 7 & $10 / 24 / 96$ & $24,612(93,156 \mathrm{~L})$ & Uninhibited condensate transfer \\
\hline 8 & $11 / 11 / 96$ & $605(2,290 \mathrm{~L})$ & No documentation available \\
\hline 9 & $11 / 17 / 96$ & $4,568(17,290 \mathrm{~L})$ & Uninhibited condensate transfer \\
\hline
\end{tabular}




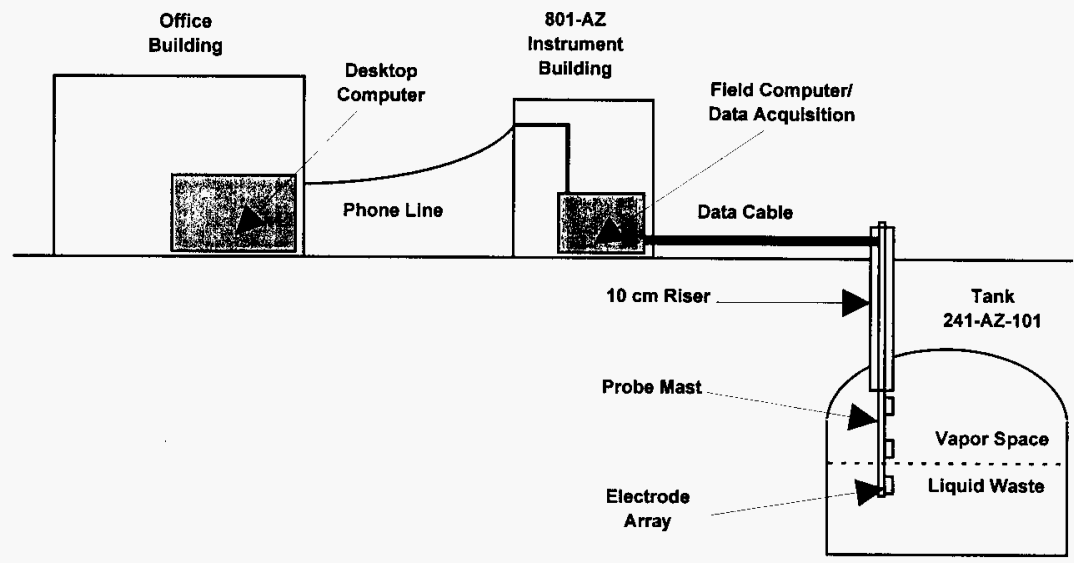

Figure 1: Schematic of Hanford Site prototype corrosion monitoring system with remote operation capability 


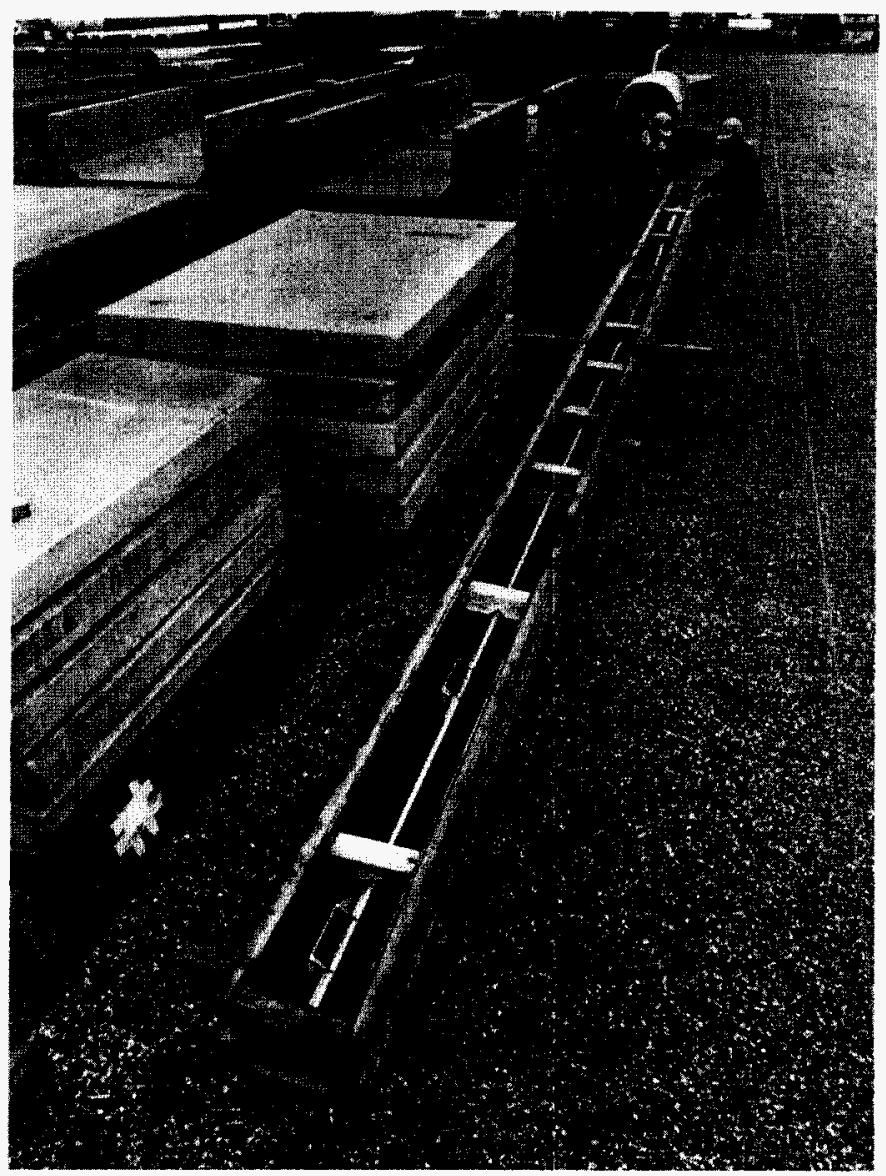

Figure 2: $\quad$ Prototype probe in lay-up yard prior to installation in double shell tank 241-AZ-101 


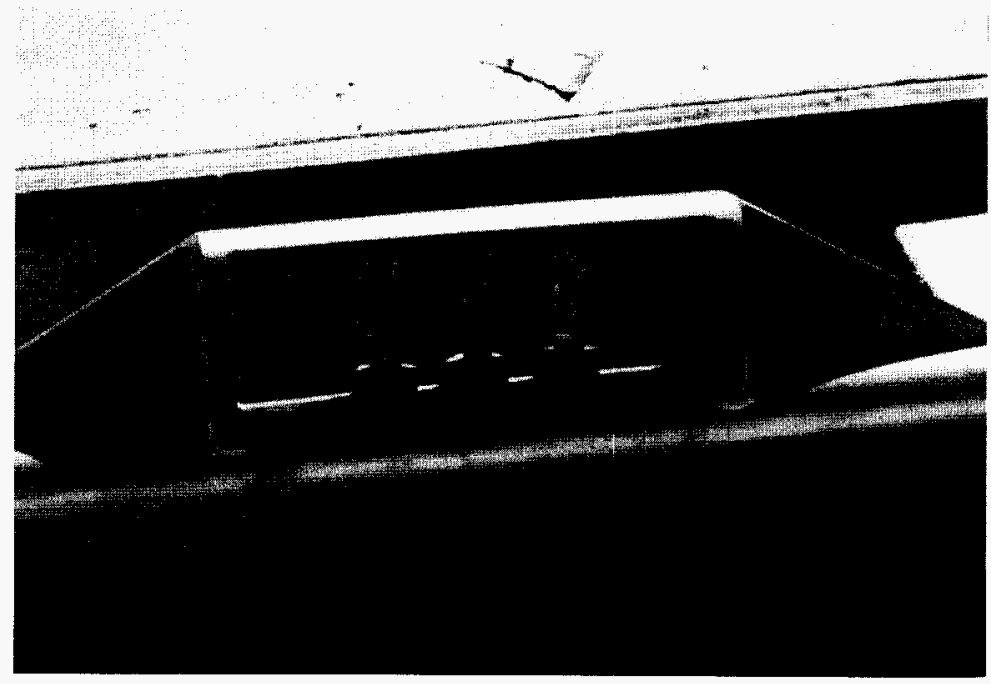

Figure 3: Close-up of C-ring electrode array on prototype probe. Center electrode is pre-cracked by cyclic fatigue then strained beyond the proportional limit (near yield) prior to installation. 


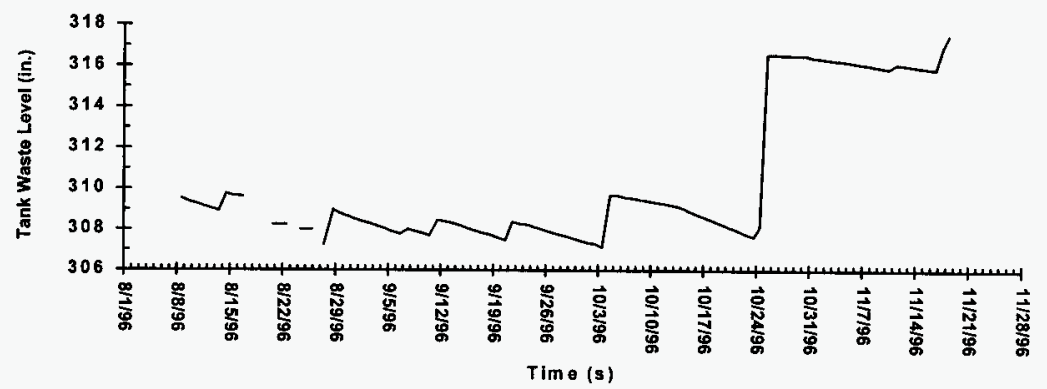

Figure 4: Water additions to tank 241-AZ-101 over first four months of prototype operation. Effect of gauge replacement on $8 / 28 / 96$ also evident.

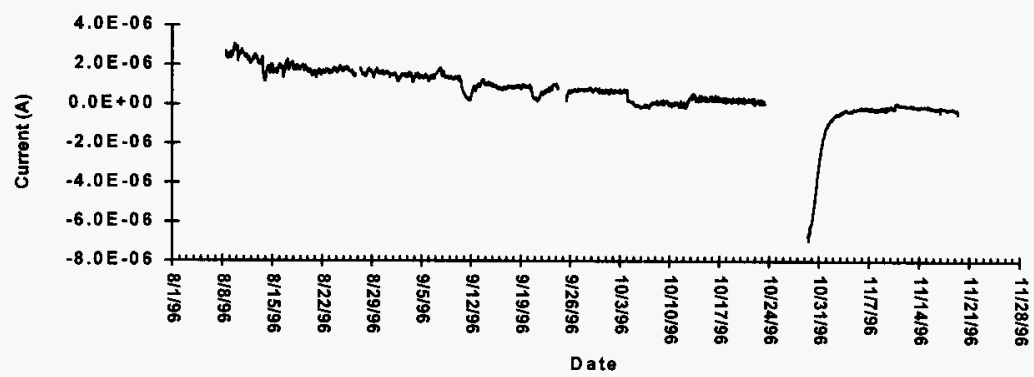

Figure 5: Mean current recorded on liquid array over first four months of prototype operation. Effects of water additions on 9/10/96, 9/20/96, 10/3/96, and 10/24/96 are evident. Mean current temporarily decreases following water additions due to upwelling of rich hydroxide solution from lower in the tank causing a temporary reduction in uniform corrosion rate. 


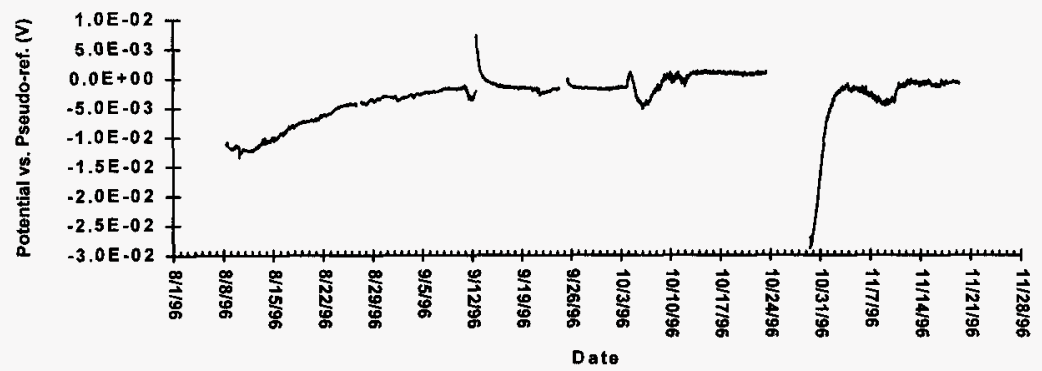

Figure 6: Mean potential recorded on liquid array over first four months of prototype operation. Effects of water additions on 9/10/96, 9/20/96, 10/3/96, and 10/24/96 are evident.

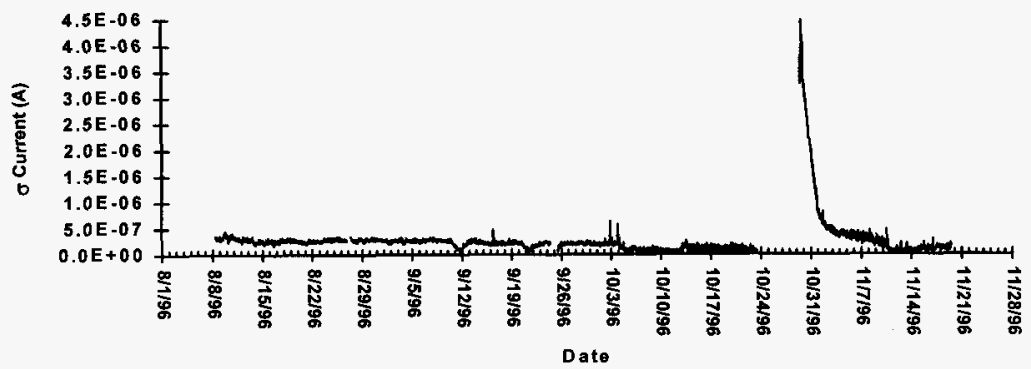

Figure 7: Standard deviation of current recorded on liquid array over first four months of prototype operation. The effect of water additions on 9/10/96, 9/20/96, 10/3/96, and 10/24/96 are also evident. Severe increase in current fluctuations associated with initiation of pitting following the $10 / 24 / 96$ water addition. 


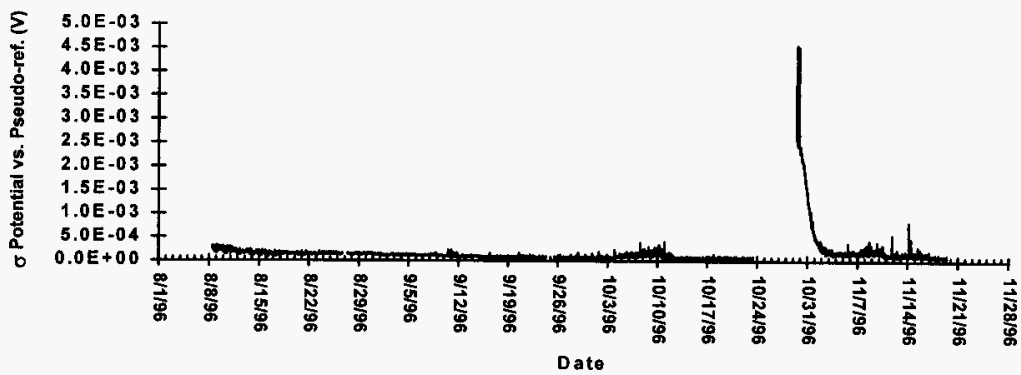

Figure 8: $\quad$ Standard deviation of potential recorded on liquid array over first four months of prototype operation. Effects of water additions on 9/10/96, 9/20/96, and 10/3/96 water additions barely evident. Temporary increase in pitting following 10/24/96 water addition appears as a temporary increase in standard deviation of potential.

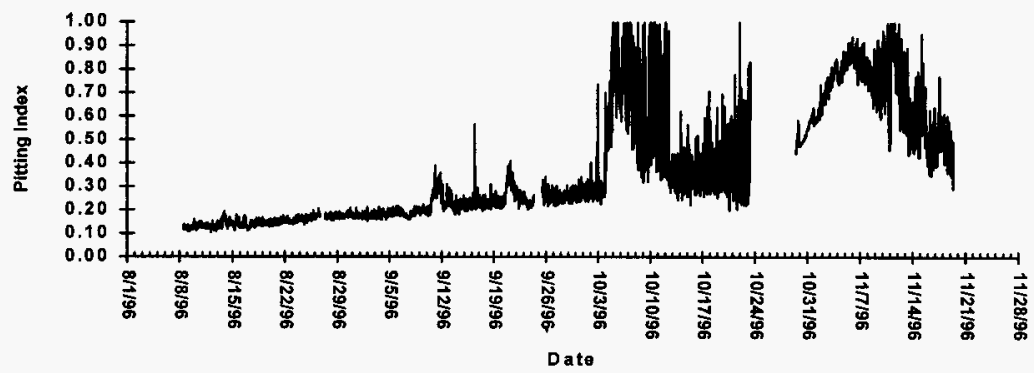

Figure 9: Pitting index recorded on liquid array over first four months of prototype operation. Severe temporary increases following water additions on 10/3/96 and 10/24/96 correspond to the initiation of pitting followed by tank re-equilibration and a return to uniform corrosion. 


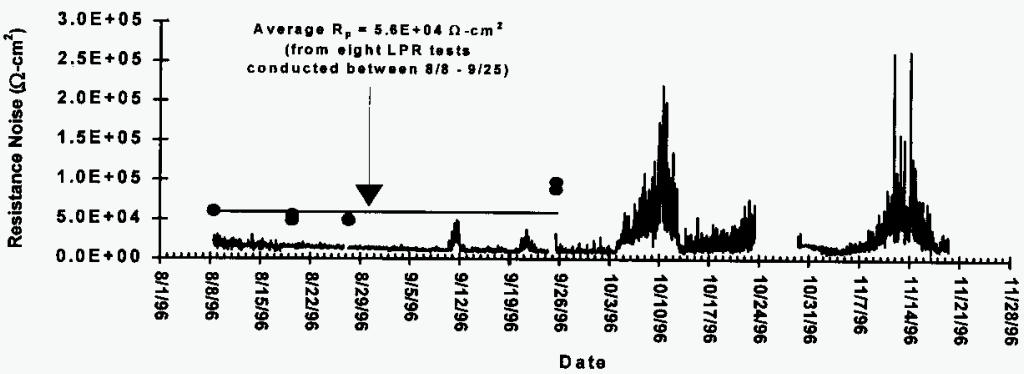

Figure 10: Resistance noise $\left(R_{n}\right)$ and polarization resistance $\left(R_{p}\right)$ data for the first four months of operation. Water additions cause an upwelling of hydroxide leading to an increase in passivity, an increase in charge transfer resistance, and an increase in $R_{n}$. LPR testing indicates that $R_{p}$ is approximately 3.6 times greater than $R_{n}$.

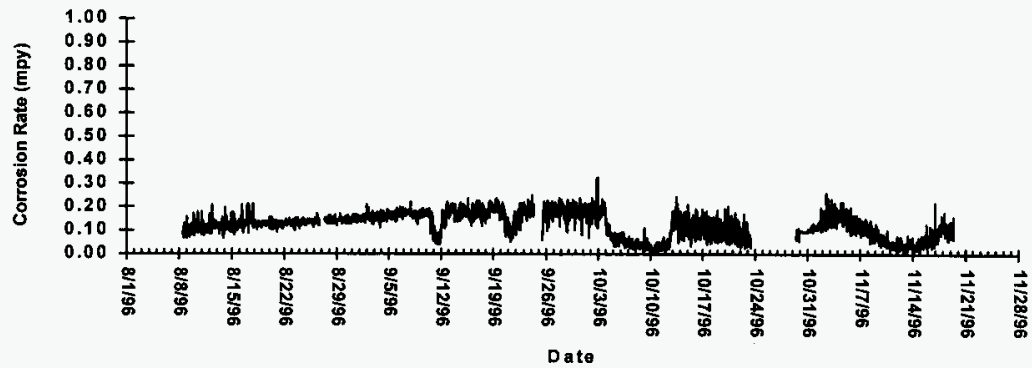

Figure 11: Corrosion rates estimated from $\mathrm{R}_{n}$ data. Immediate drops in corrosion rate associated with water additions due to upwelling of hydroxide and an increase in passivity. 


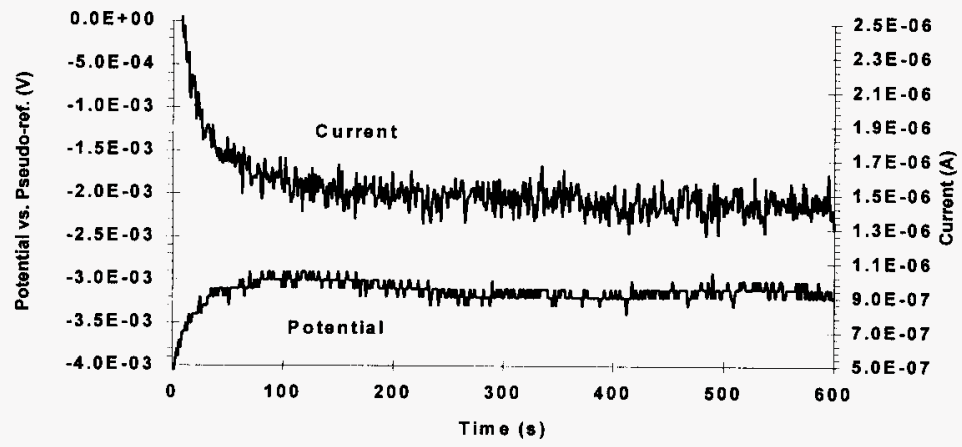

Figure 12: Typical raw data file collected prior to $9 / 10 / 96$ water addition. Data has been shown to be characteristic of uniform corrosion.

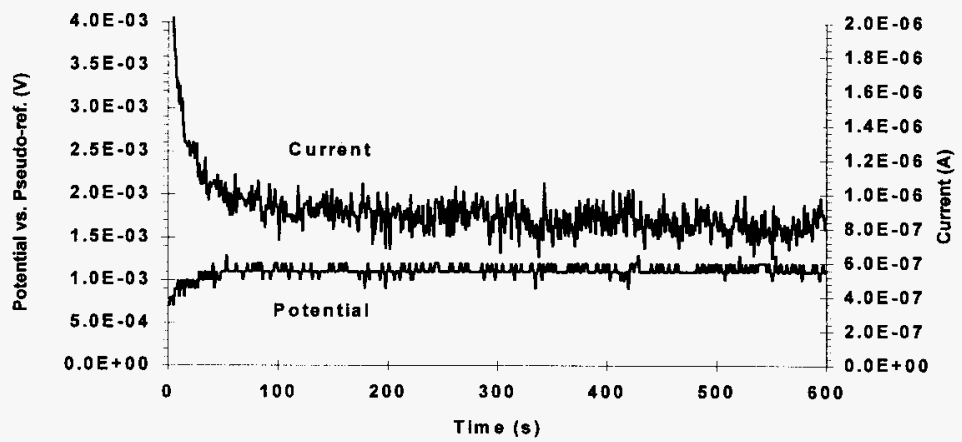

Figure 13: Typical raw data file collected after 9/10/96 water addition. Data has been shown to be characteristic of uniform corrosion. Water addition did not induce any localized corrosion. 


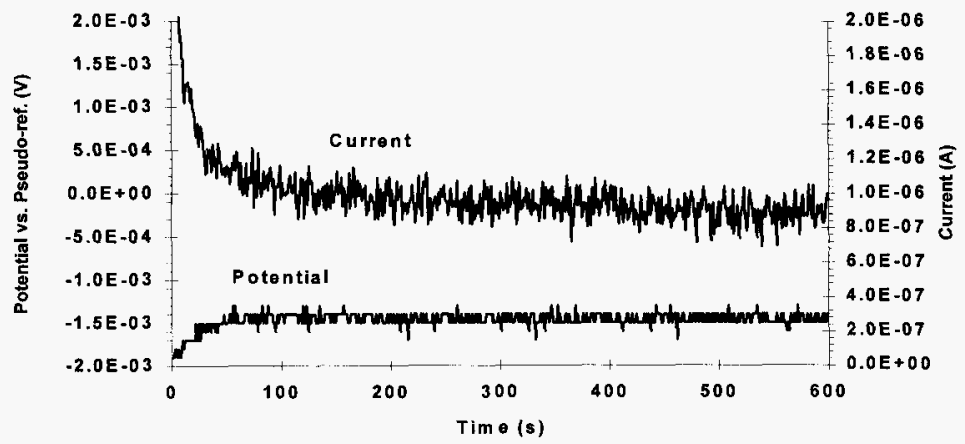

Figure 14: Typical raw data file collected prior to $9 / 20 / 96$ water addition. Data has been shown to be characteristic of uniform corrosion.

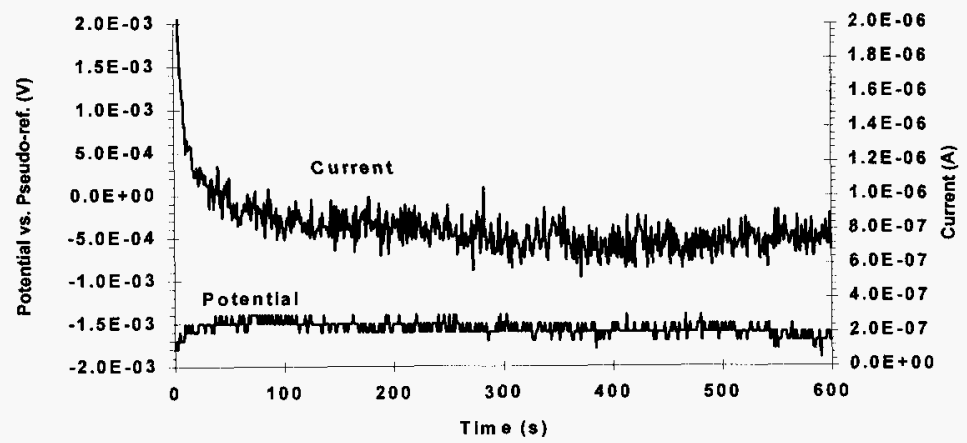

Figure 15: Typical raw data file collected after 9/20/96 water addition. Data has been shown to be characteristic of uniform corrosion. Water addition did not induce any localized corrosion. 


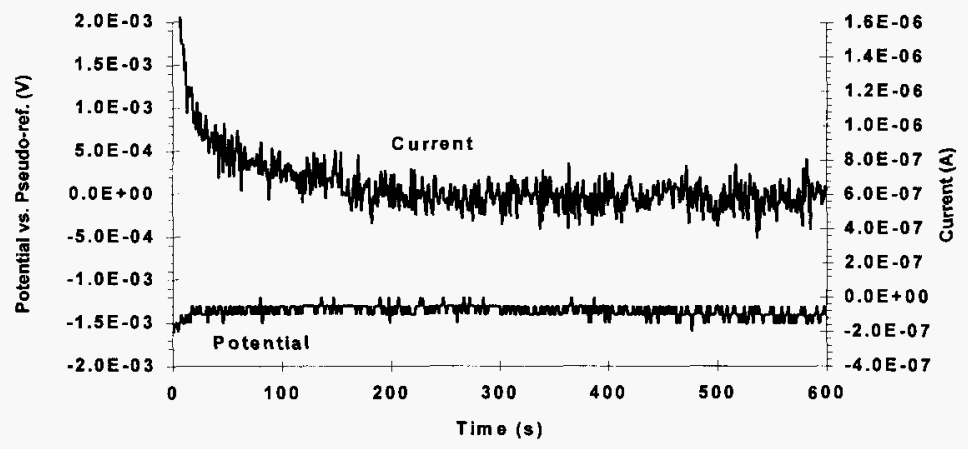

Figure 16: Typical raw data file collected prior to $10 / 3 / 96$ water addition. Data has been shown to be characteristic of uniform corrosion.

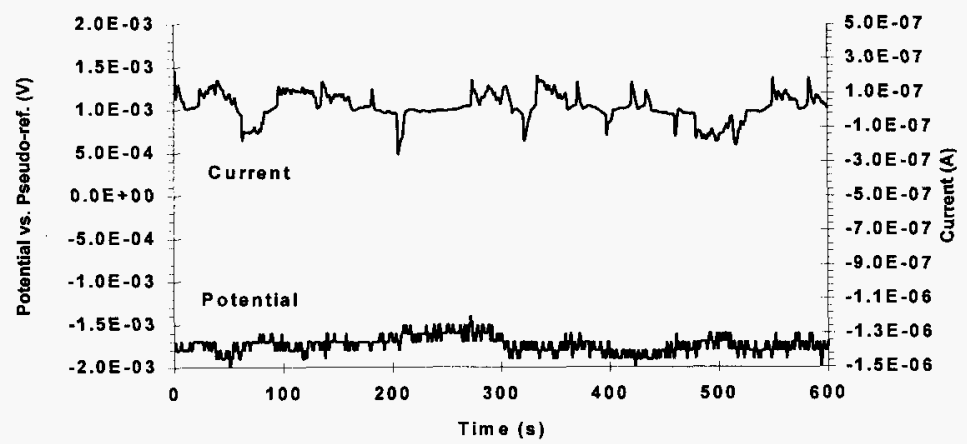

Figure 17: Typical raw data file collected after 10/3/96 water addition. Data has been shown to be characteristic of pit initiation and growth. Water addition induced pit initiation. Pit frequency and magnitude decreased steadily over the course of two weeks before a return to uniform corrosion was complete. 
WHC-SD-WM-TI-796

Rev. 0

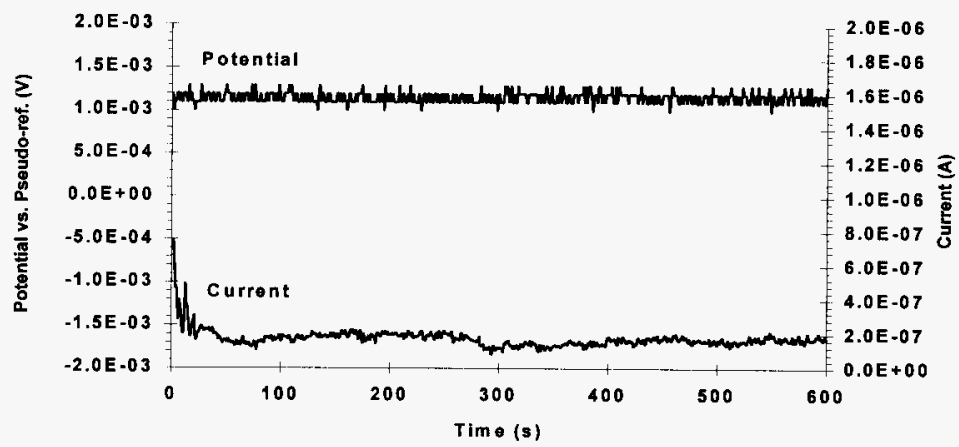

Figure 18: Raw data file collected approximately two weeks after 10/3/96 water addition, just prior to the 10/24/96 water addition. Uniform corrosion has returned as dominant corrosion mechanism.

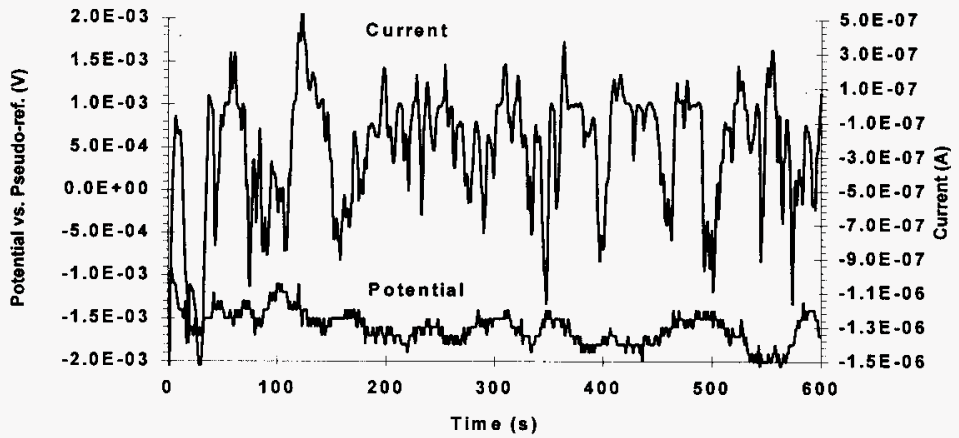

Figure 19: Typical raw data file collected 12 days after 10/24/96 water addition. Water addition has caused a return to pit initiation and growth. 
Rev. 0

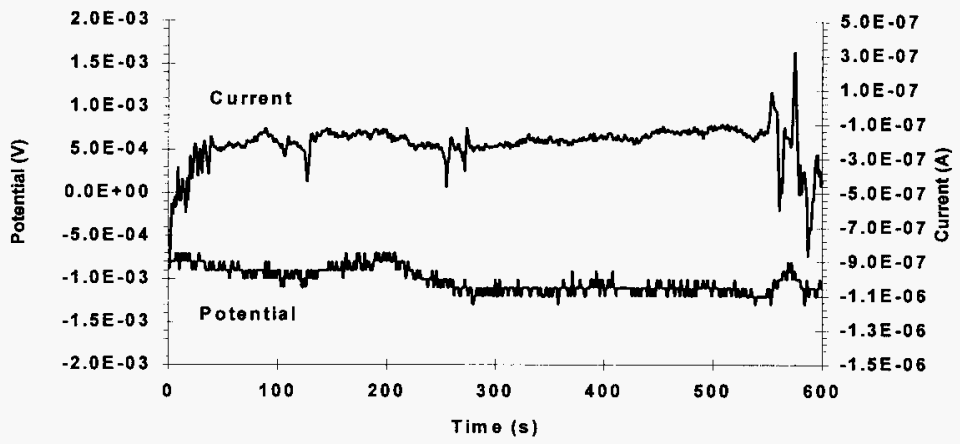

Figure 20: Raw data file collected approximately 23 days after 10/24/96 water addition. Subsequent water additions on 11/11/96 and 11/17/96 have kept tank waste in a pitting regime. The frequency and magnitude of pit transients is steadily declining and a return to uniform corrosion is expected. 
DISTRIBUTION SHEET

\begin{tabular}{l|l|l}
\hline To \\
TWRS Transition Projects & $\begin{array}{l}\text { From } \\
\text { Materials \& Corrosion } \\
\text { Engineering }\end{array}$ & Page 1 of 3 \\
\cline { 2 - 2 } $\begin{array}{l}\text { Project Title/Work Order } \\
\begin{array}{l}\text { Tank 241-AZ-101 Prototype Corrosion Probe Four Month Status } \\
\text { Report }\end{array}\end{array}$ & EDT No. 619386 \\
\cline { 2 - 2 } & ECN No. N/A \\
\hline
\end{tabular}

\begin{tabular}{|c|c|c|c|c|c|}
\hline Name & MSIN & $\begin{array}{c}\text { Text } \\
\text { With All } \\
\text { Attach. }\end{array}$ & Text Only & $\begin{array}{c}\text { Attach./ } \\
\text { Appendix } \\
\text { Only }\end{array}$ & $\begin{array}{c}\text { EDT/ECN } \\
\text { Only }\end{array}$ \\
\hline $\begin{array}{l}\text { R. P. Anantatmula } \\
\text { N. G. Awadalla } \\
\text { W. B. Barton } \\
\text { T. M. Blaak } \\
\text { J. G. Burton } \\
\text { K. G. Carothers } \\
\text { A. M. Choho } \\
\text { M. J. Daniel son (PNNL) } \\
\text { R. A. Dodd } \\
\text { G. L. Edgemon (15 copies) } \\
\text { W. M. Funderburke } \\
\text { J. E. Geary } \\
\text { T. C Geer } \\
\text { B. J. Harp (DOE-RL) } \\
\text { C. E. Jensen } \\
\text { R. H. Jones (PNNL) } \\
\text { N. W. Kirch } \\
\text { J. P. Lafemina } \\
\text { G. T. Maclean } \\
\text { W. C. Mi1ler } \\
\text { J. L. Nelson } \\
\text { P. C. Ohl (15 copies) } \\
\text { N. J. Olson (PNNL) } \\
\text { S. G. Pitman (PNNL) } \\
\text { R. S. PopielarcZyk } \\
\text { W. J. Powel1 } \\
\text { D. A. Reynolds } \\
\text { S. H. Rifaey } \\
\text { W. E. Ross } \\
\text { C. C. Scaief III } \\
\text { E. B. Schwenk } \\
\text { K. V. Scott } \\
\text { J. P. Sloughter } \\
\text { J. P. Strehlow } \\
\text { G. R. Tardiff } \\
\text { D. J. Washenfelder } \\
\text { D. D. Wodrich (DOE-RL) } \\
\text { Central Files (Orig }+2 \text { copies) }\end{array}$ & 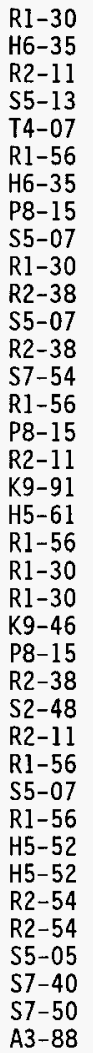 & $\begin{array}{l}X \\
X \\
X \\
X \\
X \\
X \\
X \\
X \\
X \\
X \\
X \\
X \\
X \\
X \\
X \\
X \\
X \\
X \\
X \\
X \\
X \\
X \\
X \\
X \\
X \\
X \\
X \\
X \\
X \\
X \\
X \\
X \\
X \\
X \\
X \\
X \\
X \\
X\end{array}$ & & & \\
\hline
\end{tabular}


EXTERNAL DISTRIBUTION

\begin{tabular}{c|c|c|c|c|c}
\hline Name & MSIN & $\begin{array}{c}\text { Text } \\
\text { With All } \\
\text { Attach. }\end{array}$ & Text Only & $\begin{array}{c}\text { Attach./ } \\
\text { Appendix } \\
\text { Only }\end{array}$ & $\begin{array}{c}\text { EDT/ECN } \\
\text { Only }\end{array}$ \\
\hline
\end{tabular}

\section{OFFSITE}

ChemMet, Ltd. , PC

P.0. Box 4068

West Richland, WA 99353-0017

J. Divine

$x$

M. J. Schiff \& Associates

$1291 \mathrm{~N}$. Indian Hill Blvd.

Claremont, CA 91711-3897

G. Bell

$x$

DOE-HQ

Office of Safety and Health

Germantown, Maryland 20874
J. Tseng
$E M-4$
D. Pepson
$E M-362$
$x$
$x$

West Valley Nuclear Services

10282 Rock Springs Rd.

P. 0. Box 191

West Valley, NY 14171-0191

J. Chang

D. Meess

$X$
$X$

Westinghouse Savannah River Company

P. 0. Box 616

Aiken, S.C. 29802
N. Iyre
C. Jenkins
B. Lewis
J. Mickalonis
R. Sindelar
B. Weirsma
P. Zapp

$X$
$X$
$X$
$X$
$X$
$X$
$X$ 
EXTERNAL DISTRIBUTION

\begin{tabular}{c|c|c|c|c|c}
\hline Name & MSIN & $\begin{array}{c}\text { Text } \\
\text { With All } \\
\text { Attach. }\end{array}$ & Text Only & $\begin{array}{c}\text { Attach./ } \\
\text { Appendix } \\
\text { Only }\end{array}$ & $\begin{array}{c}\text { EDT/ECN } \\
\text { Only }\end{array}$ \\
\hline
\end{tabular}

OFFSITE

Oak Ridge National Laboratory

P. 0. Box 2008

MSIN RI-56

Oak Ridge, TN 37831

J. Distefano

J. Keiser

S. Pawel

D. Wilson

$$
\begin{aligned}
& x \\
& x \\
& x \\
& x
\end{aligned}
$$

Brookhaven National Laboratory

Building 475C

Upton, NY 11973

K. Bandyopadhyay

$x$

Los Al amos National Laboratory

TSA-11, MS K557

Los Alamos, NM 87545

L. H. Sullivan

$x$

Corrosion Monitoring Service Company

P.0. Box 211

Newark, DE 19715-0211

C. Bovankovich

$x$ 